\title{
PERLINDUNGAN HUKUM TERHADAP PRODUK INDIKASI GEOGRAFIS KOPI ARABIKA JAVA SINDORO-SUMBING
}

\author{
M. Rangga Yusuf \\ E-mail: ranggayusuf56@gmail.com \\ Mahasiswa Fakultas Hukum Universitas Sebelas Maret \\ Hernawan Hadi \\ E-mail: hernawanhadi@gmail.om \\ Dosen Fakultas Hukum Universitas Sebelas Maret
}

\begin{abstract}
This article aims to examine the legal issues and to find out the the law enforcement of Geographical Indication dispute settlement. The method for this research is empirical law research (sociology/non-doctrinal). The descriptive research category and object of this research in Farmers Group of Bina Sejahtera and Association of Geographical Indication Protector of Kopi Arabika Java Sindoro-Sumbing is analyzed by interviewing the law effectiveness action and also using qualitative analysis approach. The result of this research shows that the law protection for Kopi Arabika Java Sindoro-Sumbing's Geographical Indication has given the right and protection for it. Based on juridical aspect it has been regulated in Law Number 20 of 2016 about trademark and Geographical Indication Jo. Government Regulation Number 51 of 2007 about Geographical Indication. Yet in the practical fact those laws have not work as they should be. Due to many violations of the using of Geographical Indication right and also the violation cases settlement that hasn't been continued. So that, the law enforcement is needed to solve the settlement on Geographical Indication violations, either with litigation or non-litigation.
\end{abstract}

Key Words: Law Protection; Geographical Indication; Kopi Arabika Java Sindoro-Sumbing.

\begin{abstract}
Abstrak
Artikel ini bertujuan mengkaji isu hukum dan untuk mengetahui upaya hukum penyelesaian sengketa dibidang Indikasi Geografis. Metode penelitian yang digunakan adalah penelitian hukum empiris (sosiologis/ non doktrinal). Sifat penelitian deskriptif dan obyek penelitian di Kelompok Tani Kopi Bina Sejahtera dan Masyarakat Pelindung Indikasi Geografis Kopi Arabika Java Sindor-Sumbing dilakukan dengan wawancara terhadap efektivitas hukum dan pendekatan analisis kualitatif. Hasil penelitian ini diketahui bahwa bentuk perlindungan hukum Indikasi Geografis Kopi Arabika Java Sindoro-Sumbing secara yuridis telah diatur melalui UndangUndang Nomor 20 Tahun 2016 tentang Merek dan Indikasi Geografis Jo. Peraturan Pemerintah Nomor 51 Tahun 2007 tentang Indikasi Geografis. namun dalam prakteknya perlindungan tidak berjalan sebagaimana mestinya. Karna masih terjadinya bentuk pelanggaran penggunaan tanpa hak tanda Indikasi Geografis dan masih terdapat kasus pelanggaran yang belum ditindaklanjuti dalam penyelesaiaanya. Sehingga diperlukan upaya hukum untuk menyelesaikan sengketa atas pelanggaran Indikasi Geografis baik secara non litigasi dan litigasi.
\end{abstract}

Kata Kunci: Perlindungan hukum; Indikasi Geografis; Kopi Arabika Java Sindoro-Sumbing. 


\section{A. Pendahuluan}

Hak Kekayaan Intelektual (HKI) merupakan salah satu pranata hukum yang sangat erat hubungannya dengan perdagangan. HKI secara konseptual adalah hak hukum yang diberikan atas kreasi intelektual (kekayaan intelektual) yang telah diwujudkan secara nyata ( Riswandi B.A dan Mahmashani S, 2009: 30). HKI pada umumnya berhubungan dengan perlindungan penerapan ide dan informasi yang memiliki nilai komersial (Tim Lindsey, dkk. 2005: 3). Tujuan dari perlindungan HKI adalah untuk antisipasi terjadinya pelanggaran dibidang HKI sehingga memicu persaingan usaha yang sehat dan sebagai bentuk insentif ataupun penghargaan atas kreatifitas dalam mengembangkan seni, ilmu pengetahuan, teknologi dan industri di Indonesia.

Indikasi Geografis merupakan bagian dari hak atas kekayaan intelektual yang dimana diatur dalam Undang - Undang Nomor 20 Tahun 2016 tentang Merek dan Indikasi Geografis (UU Merek dan Indikasi Geografis). Pengertian Indikasi Geografis berdasarkan Pasal 1 angka 6 UU Merek dan Indikasi Geografis adalah suatu tanda yang menunjukkan daerah asal suatu barang dan/atau produk yang karena faktor lingkungan geografis termasuk faktor alam, faktor manusia atau kombinasi dari kedua faktor tersebut memberikan reputasi, kualitas, dan karakteristik tertentu pada barang dan/atau produk yang dihasilkan. Indikasi Geografis mencakup produk pertanian atau bahan makanan yang erat kaitanya dengan wilayah geografis, tahapan produksi dan pemrosesan yang mengghasilkan ciri dan kualitas tertentu pada barang atau produk. (Claudia Diasa dan Luís Mendes, 2018: 492)

Jenis kopi yang dapat memperoleh perlindungan hukum adalah kopi yang mendeskripsikan bagaimana kopi tersebut ditanam, diproses pasca panen hingga diracik menjadi minuman kopi spesial. Istilah specialty coffee di populerkan oleh seorang wanita bernama Erna Knutsen pada tahun 1974, istilah tersebut untuk menyebut biji kopi dengan rasa terbaik yang dihasilkan dari daerah beriklim mikro istimewa (https://ekonomi.kompas.com/read /2017/07/13/172501826/kopi-indonesia-harus-mendunia. diakses pada tanggal 4 Oktober 2018 Pukul 21.00 WIB).

Terdapatnya produk Indikasi Geografis di wilayah Sindoro-Sumbing yaitu Kopi Arabika Java Sindoro-Sumbing dengan keunikan yang khas memiliki rasa pahit yang tidak berlebihan dan tingkat keasaman yang sedang dengan aroma lemon, floral, spicy, honeyed, flowery, chocolaty, dan caramel. Memberikan perlindungan Indikasi Geografis dengan nomor Sertifikat Indikasi Geografis 000000030 (http://e-book.dgip.go.id/indikasigeografis/?book=kopi-arabika-java-sindoro-sumbing. diakses pada tanggal 25 Oktober 2018 Pukul 19.00 WIB). Terdaftarnya sebagai produk Indikasi Geografis, membuat produk atau benda yang telah terdaftar tersebut menjadi milik komunal dan tidak lagi menjadi milik umum.

Meskipun sudah mendapatkan perlindungan bukan berarti terbebas dari bentuk pelanggaran, seperti kasus yang terjadi di Kabupaten Temanggung dan Wonosobo daerah yang memiliki kekayaan alam indikasi geografis kopi Arabika Java Sindoro-Sumbing. Terdapat empat kasus penyalahgunaan tanda Indikasi Geografis Kopi Arabika Java Sindoro-Sumbing. Kasus yang pertama dimulai pada tahun 2017 pemalsuan produk bermerek Kopi Bowongso yang memiliki hak Indikasi Geografis sehingga terdapat tanda Indikasi Geografis didalam kemasannya yang dipalsukan juga, dan termasuk kategori penyalahgunaan tanda Indikasi Geografis kopi Arabika Java Sindoro-Sumbing. Kasus kedua dan ketiga pada tahun 2018 
terdapat penyalahgunaan tanda Indikasi Geografis kopi Arabika Java Sindoro-Sumbing sedangkan produsen yang menggunakan tanda Indikasi Geografis kopi Arabika Java SindoroSumbing belum menjadi anggota Masyarakat Pelindung Indikasi Geografis (MPIG) Kopi Arabika Java Sindoro-Sumbing, dan kasus keempat ditahun 2018 pelaku memasukan tanda Indikasi Geografis Kopi Arabika Java Sindoro-Sumbing didalam kemasan produk kopi dengan tidak sesuai prosedur Buku Persyaratan Indikasi Geografis.

Kurangnya perlindungan optimal terhadap Indikasi Geografis menjadi suatu masalah yang harus segera diselesaikan, karna Indonesia memiliki banyak potensi ekonomi terkait Indikasi Geografis. Namun belum sepenuhnya masyarakat luas memahami pentingnya perlindungan hukum terhadap Indikasi Geografis. Fungsi dari perlindungan hukum bukan hanya sebatas pendaftaran ataupun pemberian sertifikasi saja melainkan Indikasi Geografis dapat pula meningkatkan dan mempertahankan kualitas maupun karakteristik produk sehingga diperlukan perlindungan dari pembajakan atau pemalsuan dalam wujud penuntutan gugatan ganti rugi maupun dalam bentuk pidana.

Berdasarkan dari pendahuluan tersebut, maka dalam artikel ini akan dibahas bagaimanakah upaya hukum untuk mengoptimalisasi perlindungan hak Indikasi Geografis terhadap produk Kopi Arabika Java Sindoro-Sumbing.

\section{B. Metode Penelitian}

Metode penelitian hukum yang penulis gunakan adalah metode penelitian hukum empiris atau non-doctrinal research (social legal research) bersifat bersifat deskriptif. Jenis dan sumber data penelitian yang digunakan adalah data primer dan data sekunder, data yang diperoleh langsung dari masyarakat dinamakan data primer dilakukan di Kelompok Tani Kopi Bina Sejahtera dan Masyarakat Pelindung Indikasi Geografis Kopi Arabika Java SindorSumbing dan data yang diperoleh dari bahan pustaka diberi nama data sekunder (Soerjono Soekanto, 2014:51). teknik analisis data menggunakan metode kualitatif digunakan agar penyusun dapat memahami masalah atau suatu keadan yang diteliti dengan menggunakan proses siklus dari tahap reduksi data dan sajian data saling dihubungkan untuk alur sebab akibat, akhirnya peneliti menarik kesimpulan.

\section{Hasil Penelitian dan Pembahasan}

Produk Indikasi Geografis akan mendapat perlindungan setelah didaftarkan pada Direktorat Jendral Kekayaan Intelektual Kementrian Hukum dan Hak Asasi Manusia Republik Indonesia (DJKI KEMENKUMHAM RI). Dengan didaftarkanya produk tidak dapat menjadi milik umum sehingga pihak yang tidak berada di wilayah Indikasi Geografis tidak berhak menggunakan dan mengekploitasi karna penggunaan atas tanda dari produk Indikasi Geografis telah terdaftar oleh pemegang hak yang berada diwilayah Indikasi Geografis yang telah memenuhi persyaratan yang diatur dalam Dokumen Deskripsi Indikasi Geografis. Tersertifikasinya Kopi Arabika Java Sindoro-Sumbing membuat anggota yang tergabung dalam MPIG - Kopi Arabika Java Sindoro-Sumbing dapat mengeksploitasi dan menggunakan Indikasi Geografis miliknya dengan rasa aman akibat memiliki hubungan hukum dengan barang atau objek yang menjadi kepemilikanya. Perlindungan terhadap produk Indikasi Geografis sendiri dilakukan oleh pemegang hak dan negara melalui instrumen hukum Indikasi Geografis. 
Seperti kasus yang sebelumnya telah dipaparkan, Terdapat empat kasus penyalahgunaan tanda Indikasi Geografis Kopi Arabika Java Sindoro-Sumbing. dari keempat kasus tersebut terdapat kasus yang belum terselesaikan dikarenakan kurangnya pengetahuan terhadap anggota MPIG - Kopi Arabika Java Sindoro-Sumbing dan Kelompok MPIG - Kopi Arabika Java Sindoro-Sumbing yang kurang mengawasi anggotanya sehingga kasus pelanggaran terhadap Kopi Arabika Java Sindoro-Sumbing di wilayah Bowongso tidak diketahui.

Kasus pelanggaran yang belum terselesaikan adalah produk kopi bermerek Kopi Bowongso yang menggunakan tanda Indikasi Geografis Kopi Arabika Java Sindoro-Sumbing yang dipalsukan. Anggapan dari pihak Kelompok Tani Bina Sejahtera "Bowongso" yang tergabung dalam MPIG - Kopi Arabika Java Sindoro-Sumbing, bahwa pihak Kelompok Tani Bina Sejahtera tidak bisa berbuat banyak, hanya dapat melakukan tindakan itikad baik seperti peneguran karna pihak Kelompok Tani Bina Sejahtera belum mendaftarkan Merek Bowongso di DJKI sehingga anggapan dari mereka tidak bisa melakukan upaya hukum untuk menyelesaikan perkara pemalsuan produk mereka.

Melihat ketentuan yang ada didalam Buku Persyaratan Indikasi Geografis penggunaan tanda Indikasi Geografis setelah lolos pengujian mutu oleh Tim Pengawas Mutu MPIG - Kopi Arabika Java Sindoro-Sumbing yang di hasilkan oleh masing-masing unit pengolah maka dapat menggunakan tanda Indikasi Geografis berupa nama, logo dan kode keterunutan. Sehingga pengolah kopi yang menggunakan mereknya masing-masing pada setiap kemasannya berhak menggunakan tanda Indikasi Geografis untuk menandakan bahwa produk tersebut adalah produk Indikasi Geografis.

Bentuk upaya perlindungan hukum dalam mewujudkan Indikasi Geografis terhadap Kopi Arabika Java Sindoro-Sumbing berdasarkan teori perlindungan hukum dapat dilakukan dengan dua cara yaitu perlindungan hukum preventif dan perlindungan hukum represif(Zairin Harahap, 2001: 56). Perlindungan hukum preventif adalah perlindungan yang diberikan oleh pemerintah dengan tujuan untuk mencegah sebelum terjadinya pelanggaran. Hal ini terdapat dalam peraturan perundang-undangan dengan maksud untuk mencegah suatu pelanggaran serta memberikan rambu-rambu atau batasan-batasan dalam melakukan sutu kewajiban. Sedangkan perlindungan hukum represif merupakan perlindungan akhir berupa sanksi seperti denda, penjara, dan hukuman tambahan yang diberikan apabila sudah terjadi sengketa atau telah dilakukan suatu pelanggaran. (Muchsin, 2003: 20)

Penyalahgunaan tanda Indikasi Geografis Kopi Arabika Java Sindoro-Sumbing atau peniruan terhadap suatu produk Indikasi Geografis. membuat pemegang hak atas Indikasi Geografis dapat mengajukan gugatan terhadap pemakai Indikasi Geografis yang tanpa hak berupa permohonan ganti rugi dan penghentian penggunaan serta pemusnahan etiket Indikasi Geografi. (Yusran Isnaini, 2010:139). Kopi Arabika Java Sindor-Sumbing sendiri sudah mendapatkan perlindungan Indikasi Geografis sehingga dapat dilakukan penyelesaian sengketa melalui jalur litigasi dan non litigasi ketika terjadi pelanggaran.

\section{Upaya Hukum Penyelesaian melalui Non litigasi (Arbitrase Dan Alternatif Penyelesaian Sengketa)}

Dalam Pasal 93 UU Merek dan Indikasi Geografis dinyatakan bahwa selain penyelesaian gugatan di Pengadilan Niaga para pihak dapat menyelesaikan sengketa melalui arbitrase atau alternatif penyelesaian sengketa. Cara penyelesaian sengketa dalam 
Undang-Undang Nomor 30 Tahun 1999 tentang Arbitrase dan Alternatif Penyelesaian Sengketa (UU AAPS) memiliki beberapa cara penyelesaian sengketa yaitu :

a. Konsultasi adalah suatu tindakan yang bersifat "personal" antara suatu pihak tertentu (klien) dengan pihak lain yang merupakan pihak konsultan, dimana pihak konsultan memberikan pendapatnya kepada klien sesuai dengan keperluan dan kebutuhan kliennya (Frans Hendra Winarta, 2011: 7). Biasanya konsultasi dipakai para pihak yang bersengketa sebelum tahap negosiasi.

b. Negosiasi adalah para pihak yang bersengketa berunding secara langsung atas dasar prinsip win-win. Negosiasi bersifat informal dan tidak terstruktur serta waktunya tidak terbatas, oleh karena itu efisiensi dan efektivitas negosiasi tergantung sepenuhnya pada itikad baik para pihak yang bersengketa (Adi Sulistiyono, 2008: 81). Untuk melakukan penyelesaian tanpa pihak ketiga dan didasari pada kepentingan bersama.

c. Mediasi merupakan perluasan negosiasi yang melibatkan pihak ketiga yang netral dan tidak memihak yang bisa diterima kedua belah pihak yang bersengketa. Dalam hal ini pihak mediator sebatas memberikan bantuan substantif, prosedural dan memberi saran, sedangkan otoritas membuat keputusan tetap berada pada konsensus para pihak yang bersengketa (Adi Sulistiyono, 2008: 87).

Konsiliasi berasal dari bahasa Inggris, yaitu "conciliation" yang berarti "pemufakatan” (Bambang Sutiyoso, 2006: 92). Sementara itu, dalam Kamus Hukum : Dictionary of aw Complete Edition, konsiliasi diartikan sebagai : Usaha untuk mempertemukan keinginan pihak-pihak yang bersengketa agar mencapai kesepakatan guna menyelesaikan sengketa dengan cara kekeluargaan. (Rahmi Yuniarti, 2016: 564)

d. Arbitrase, di dalam UU AAPS Pasal 1 ayat 1 menyatakan bahwa arbitrase adalah cara penyelesaian suatu sengketa perdata diluar pengadilan umum yang didasarkan pada perjanjian arbitrase yang dibuat secara tertulis oleh para pihak yang bersengketa.

Dari ketentuan Pasal 5 ayat (1) dan Pasal 66 UU AAPS menjelaskan bahwa kasus pelanggaran terhadap Indikasi dapat diselesaikan melalui arbitrase karna ruang lingkup perdaganganya mencakup HKI. arbitrase menjadi pilihan didalam penyelesaian sengketa diluar pengadilan karna menghasilkan putusan yang memaksa yang diadili oleh pihak ketiga, yaitu arbiter atau majelis arbiter. Dan dalam memilih arbiter para pihak dapat memilih yang dikehendaki sehingga akan menjamin kenetralan dan keahlian dari arbiter yang dipilih.

\section{Upaya Hukum Penyelesaian melalui jalur litigasi (Jalur Pengadilan)}

Menurut Pasal 67 ayat (1) dan ayat (2) UU Merek dan Indikasi Geografis gugatan terhadap pelanggaran dapat dilakukan oleh setiap produsen yang berhak menggunakan Indikasi Geografis; dan/atau, lembaga yang mewakili masyarakat di kawasan geografis tertentu dan yang diberi kewenangan untuk itu. Gugatan tadi didalam Pasal 85 ayat (1) sampai ayat (9) UU Merek dan Indikasi Geografis diajukan kepada ketua Pengadilan Niaga dalam wilayah hukum tempat tinggal atau domisili tergugat. Panitera menyampaikan gugatan kepada ketua Pengadilan Niaga dalam jangka waktu paling lama dua hari terhitung sejak gugatan didaftarkan dan ketua Pengadilan Niaga mempelajari gugatan dan menunjuk majelis hakim untuk menetapkan hari sidang paling lama tiga hari sejak tanggal gugatan disampaikan. 
Pemanggilan para pihak dilakukan oleh juru sita paling lama tujuh hari setelah gugatan didaftarkan. Dilanjutkan dengan sidang pemeriksaan sampai putusan atas gugatan diselesaikan paling lama sembilan puluh hari setelah perkara diterima oleh majelis dan diperpanjang paling lama tiga puluh hari atas persetujuan Ketua Mahkamah Agung. Putusan atas gugatan harus diucapkan dalam sidang terbuka untuk umum dan isi putusan wajib disampaikan oleh juru sita kepada para pihak paling lama empat belas hari setelah putusan atas gugatan.

Kewenangan mengadili sengketa atau perkara gugatan pelanggaran Indikasi Geografis berada diperadilan khusus yaitu Pengadilan Niaga. Pemberdayaan Pengadilan Niaga bertujuan untuk sengketa merek ataupun Indikasi Geografis dapat diselesaikan dalam waktu relatif singkat dan cepat. Mengingat Indikasi Geografis merupakan bagian dari kegiatan perekonomian sehingga penyelesaiannya memerlukan badan peradilan khusus, yaitu Pengadilan Niaga.

Berdasarkan prosedur penyelesaian sengketa melalui litigasi tersebut diatas, maka penulis dapat memberikan suatu analisa sebagai berikut:

Menurut UU Merek dan Indikasi Geografis Pasal 101 ayat (2) yang menyatakan bahwa Setiap Orang yang dengan tanpa hak menggunakan tanda yang mempunyai persamaan pada pokoknya dengan Indikasi Geografis milik pihak lain untuk barang dan/atau produk yang sama atau sejenis dengan barang dan/atau produk yang terdaftar, dipidana dengan pidana penjara paling lama 4 (empat) tahun dan/atau denda paling banyak Rp2.000.000.000,00 (dua miliar rupiah). Berdasarkan ketentuan Pasal 101 ayat (2) UU Merek dan Indikasi Geografis, menurut pendapat penulis tindakan yang dilakukan oleh pelaku merupakan tindak pidana dibidang Indikasi Geografis. Karena tindakan yang dilakukan oleh pelaku memenuhi unsur-unsur tindak pidana pemalsuan tanda Indikasi Geografis yang termuat dalam Pasal 101 ayat (2) yang berupa : dengan tanpa hak menggunakan tanda yang mempunyai persamaan pada pokoknya dengan tanda Indikasi Geografis milik pihak lain.

Seharusnya pihak Kelompok Tani Bina Sejahtera yang memproduksi dan mengelola kopi dengan merek Bowongso dapat memberitahukan MPIG - Kopi Arabika Java Sindoro-Sumbing untuk dilakukan permohonan pelaporan pelanggaran atas penggunaan tanpa Indikasi Geografis kepada pejabat penyidik Kepolisian Negara Republik Indonesia atau pejabat penyidik pegawai negeri sipil. Karna menurut ketentuan Pasal 103 UU Merek dan Indikasi Geografis menyatakan bahwan tindak pidana sebagaimana dimaksud dalam Pasal 100 sampai dengan Pasal 102 merupakan delik aduan. Artinya, tindak pidana dibidang Indikasi Geografis tidak dapat dituntut kecuali sebelumnya ada pengaduan dari pemilik atau pemegang hak Indikasi Geografis tersertifikasi.

MPIG - Kopi Arabika Java Sindoro-Sumbing dalam perkara ini harus mengajukan gugatan yang dilandasi bahwa MPIG - Kopi Arabika Java Sindoro-Sumbing merupakan pemilik hak atas Indikasi Geografis Kopi Arabika Java Sindoro-Sumbing dengan nomor Sertifikat Indikasi Geografis 000000030 yang terbagi dalam dua wilayah Kabupaten Wonosobo dan Kabupaten Temanggung. Sehingga pihak yang berada di luar wilayah Indikasi Geografis tidak berhak menggunakan dan mengekploitasi karna penggunaan atas tanda dari produk Indikasi Geografis telah terdaftar oleh pemegang hak yang berada 
diwilayah Indikasi Geografis yang telah memenuhi persyaratan sebagaimana diatur dalam Buku Persyaratan Indikasi Geografis. Dengan demikian menurut Pasal 69 UU Merek dan Indikasi Geografis MPIG - Kopi Arabika Java Sindoro-Sumbing berhak untuk mengajukan gugatan atas pemakaian Indikasi Geografis dan menuntut pelaku untuk ganti rugi, penghentian penggunaan serta pemusnahan tanda Indikasi Geografis Kopi Arabika Java Sindoro-Sumbing.

Pelaksanaan putusan harus menyatakan bahwa MPIG - Kopi Arabika Java SindoroSumbing adalah pemegang hak Indikasi Geografis atas tanda Indikasi Geografis Kopi Arabika Java Sindoro-Sumbing. Dan pelaku secara tanpa hak telah menggunakan tanda Indikasi Geografis Kopi Arabika Java Sindoro-Sumbing yang memiliki persamaan pada pokoknya sehingga dalam putusan harus memerintahkan pelaku untuk menghentikan produksi, peredaran, dan atau perdagangan barang yang menggunakan tanda Indikasi Geografis Kopi Arabika Java Sindoro-Sumbing dan memberikan sanksi pidana penjara paling lama 4 (empat) tahun dan/atau denda paling banyak Rp2000.000.000,00 (dua miliar rupiah) sesuai ketentuan Pasal 101 ayat (2). Pertimbangan lainya karna produk Indikasi Geografis Kopi Arabika Java Sindoro-Sumbing sudah sangat terkenal dengan terjaganya kualitas dan karakteristik dari produk kopi sehingga perlu mendapatkan perlindungan hukum. serta pemakaian tanda Indikasi Geografis Kopi Arabika Java Sindoro-Sumbing dilandasi oleh itikad tidak baik untuk menunjukkan bahwa produk tersebut sebanding kualitasnya dengan produk yang dilindungi oleh Indikasi Geografis dan menyesatkan masyarakat sehubungan dengan asal-usul tempat produk.

\section{Simpulan}

Berdasarkan penjelasan hasil penelitian dan pembahasan, maka dapat disimpulkan bahwa tersertifikasinya produk Indikasi Geografis Kopi Arabika Java Sindoro-Sumbing memberikan perlindungan hukum bagi pemilik hak Indikasi Geografis. Namun dalam prakteknya, perlindungan preventif belum dapat berjalan dengan maksimal, karena terdapat bentuk pelanggaran penggunaan tanpa hak terhadap tanda Indikasi Geografis dan masih terdapat kasus pelanggaran yang belum ditindaklanjuti dalam penyelesaiaanya. Sehingga diperlukan upaya hukum untuk menyelesaikan sengketa yaitu perlindungan represif terhadap produk Kopi Arabika Java Sindor-Sumbing tersertivikasi dengan proses penyelesaian sengketa Indikasi Geografis berdasarkan UU Merek dan Indikasi Geografis dapat ditempuh melalui jalur non litigasi dan litigasi. Penyelesaian sengketa secara non litigasi adalah penyelesaian diluar pengadilan, seperti Arbitrase dan Alternatif Penyelesaian Sengketa sebagaimana diatur dalam Pasal 93 UU Merek dan Indikasi Geografis. Sedangkan Penyelesaian sengketa secara litigasi adalah penyelesaian melalui lembaga pengadilan yaitu pengadilan niaga dengan gugatan ganti rugi maupun dalam bentuk pidana.

\section{E. Saran}

1. Kepada Pemerintah, khususnya Kementerian Hukum dan HAM, perlu melakukan sosialisasi terkait Indikasi Geografis kepada pihak produsen sebagai pemegang hak. Sampai ke tahap pelaku usaha dan konsumen, untuk meminimalisir penggunaan tanpa hak tanda Indikasi Geografis. Lalu melakukan pengawasan dalam proses pemasaran produk Indikasi Geografis Kopi Arabika Java Sindoro-Sumbing dan menindak lanjuti 
kasus pelanggaran Indikasi Geografis serta menindak secara tegas pihak yang melakukan pelanggaran Indikasi Geografis.

2. Kepada MPIG - Kopi Arabika Java Sindoro-Sumbing sebagai pemilik hak Indikasi Geografis perlu adanya penguatan internal agar dapat menjaga kualitas dan karakteristik dari produk Kopi Arabika Java Sindoro-Sumbing. Terjadinya pelanggaran terhadap tanda Indikasi Geografis seharusnya MPIG - Kopi Arabika Java Sindoro-Sumbing melaporkan pelanggaran Indikasi Geografis kepada pejabat penyidik Kepolisian Negara Republik Indonesia atau pejabat penyidik pegawai negeri sipil. Sehingga dapat segera dilakukan penyelidikan dan dapat diadili di Pengadilan Niaga.

\section{F. Daftar Pustaka}

\section{Buku dan Artikel Ilmiah}

Adi Sulistiyono. 2008. Eksistensi dan Penyelesaian Sengketa HaKI. Surakarta: LPP UNS dan UNS Press.

Claudia Diasa, Luís Mendes. 2018. "Protected Designation of Origin (PDO), Protected Geographical Indication (PGI) and Traditional Speciality Guaranteed (TSG): A bibiliometric analysis". Food Research International, 103 (2018) 492-508

Frans Hendra WInarta. 2011. Hukum Penyelesaian Sengketa-Arbitrase Nasional Indonesia \& Internasional. Jakarta: Sinar Grafika.

Muchsin. 2003. "Perlindungan dan Kepastian Hukum bagi Investor di Indonesia”. Tesis. Surakarta: Magister Ilmu Hukum Universitas Sebelas Maret.

Rahmi Yuniarti. 2016. "Efisiensi Pemilihan Alternatif Penyelesaian Sengketa Dalam Penyelesaian Sengketa Waralaba". Fiat Justisia Journal of Law. Volume 10 Issue 3, July-September 2016. Lampung: Fakultas Hukum Universitas Lampung

Riswandi B.A dan Mahmashani S. 2009. Dinamika Hak Kekayaan Intelektual dalam Masyarakat Kreatif. Yogyakarta: Total Media.

Soerjono Soekanto. 2014. Pengantar Penelitian Hukum. Jakarta: UI Press.

Bambang Sutiyoso. 2006. Penyelesaian Sengketa Bisnis: Solusi dan Antisipasi bagi Peminat Bisnis dalam menghadapi Sengketa kini dan mendatang. Yogyakarta: Citra Media Hukum.

Tim Lindsey, dkk. 2005. Hak Kekayaan Intelektual: Suatu Pengantar. Bandung: Asian Law Group.

Yusran Isnaini. 2010. Buku Pintar HAKI. Bogor: Ghalia Indonesia.

Zairin Harahap. 2001. Hukum Acara Peradilan Tata Usaha Negara. Jakarta: Raja Grafindo Persada. 
M. Rangga Yusuf, Hernawan Hadi. Perlindungan Hukum terhadap Produk Indikasi ...

\section{Internet}

Kompas. 2017. https://ekonomi.kompas.com/read/2017/07/13/172501826/kopi-indonesia-harusmendunia. diakses pada tanggal 4 Oktober 2018 Pukul 21.00 WIB.

http://e-book.dgip.go.id/indikasi-geografis/?book=kopi-arabika-java-sindoro-sumbing. diakses pada tanggal 25 Oktober 2018 Pukul 19.00 WIB. 